\title{
Petty corruption on firm level innovation of MSMEs: Evidence from emerging economies
}

\author{
Nirosha Hewa Wellalage \\ School of accounting, Finance and Economics, The University of Waikato, New Zealand \\ Email:nirosha@waikato.ac.nz
}

\begin{abstract}
In this study, we examine how petty corruption affects micro, small and medium firms (MSMEs)'s innovation in emerging economies. Innovators from emerging economies face considerably high bribing pressure from corrupt public officials and no or little institutional support for innovative firms (Kotabe, Jiang, \& Murray, 2017). Corruption undermines the foundations of institutional trust, which is necessary to develop entrepreneurial and innovative activities. It has been argued that corruption increases transaction costs, which makes innovative opportunity much less attractive. Since innovators have been recognised as the main driver of long-term economic growth, a clear understanding of how corruption affects innovation can assist the MSMEs development.

Our examination of the relationship between innovation and corruption uses firm-level data for 3368 MSMEs in South American countries. We observe some firms that pay bribes and others that do not, but a direct comparison between them leads to an identification problem because the engagement with bribery may correlate with unobserved determinants of firms. To overcome this potential bias, we use propensity score matching (PSM) to find a comparison group for individual firms in the bribe-paying group. After controlling for firm characteristics and taking care of firms' observable characteristics typically linked to innovation decisions, we find systematic differences in firm-level innovation activities associated with paying bribes. In particular, results indicate that the estimated average effect of paying bribes on innovation outcome for firms who engaged in bribery is 11 percent. However, significant heterogeneity in innovation and paying bribes is also observable. Empirically, we find that the average effect of paying bribes on innovations is significantly higher on process innovation outcome than product innovation. We also observe that with weaker institutions, the effects of bribery on innovation is more pronounced. The main knowledge contribution of this paper is twofold. First, to the best of our knowledge, this paper is the first investigation of innovation in MSMEs from the perspective of innovation and corruption, using cross country micro-data, which are rich and recent. Also, extending prior research, we further report a heterogeneity effect of paying bribes on product and process innovations. Prior innovation studies, which use micro-data, mainly examine a single country Comparative studies using micro-data focus on large firms in developed markets.Policy derived from these large firm and mature market studies seems problematic for MSMEs in emerging economies, given the size effects, corruption levels etc. Second, this study provides a fresh perspective to that of previous studies of corruption in emerging economies, highlighting the importance of formal institutions in dealing with corruption. While prior studies on the role of institutions has focused on mianly formal tension (CuervoCazurra, 2006, 2008), this study emphasizes the importance of the local environment in gaining legitimacy in the role of innovative entrepreneurs or MSMEs. In emerging economies, ineffective legal enforcement of contracts, weak regulations, and difficulty in enforcing property rights encourages private entrepreneurs to rely on informal forms of security (Ahlstrom, Bruton, \& Lui, 2000). Consequently, informal ties and relational governance tend to fill the 'institutional void' where there is inadequate formal institutional infrastructure
\end{abstract}

Keywords: Corruption, innovation, bribes, MSMEs, credit access, emerging countries 


\section{INTRODUCTION}

Corruption remains as the greatest obstacle for sustainable economic development (Nations, 2006) and has been a topic of debate for over 50 years. In recent years, corruption has attracted much attention by economists and policymakers as it underpins social, cultural, and political discrimination by weakening the access to public resources, information and decision-making. Corruption is defined as acceptance or extortion of money for private benefit by government officials(Tanzi \& Davoodi, 1997). However, the debate is whether all these illegal payments are harmful for the economic activities such as productivity, trade, foreign investment, entrepreneurship, or innovation (Krammer, 2017). In the growing stream of research on corruption, the relationship between corruption and innovation has received scant attention (Anokhin, Schulze, 2009).

The literature on the effects of corruption on innovation has two opposing views. One branch of literature depicts corruption as being sand in the wheels, where corruption is likely to have detrimental effects on firms (Fungáčová, Kochanova, \& Weill, 2015; Mauro, 1995; Reinikka \& Svensson, 2005). The opposite view argues that corruption greases the wheels, claiming that in emerging economies corruption is likely to have beneficial effects for firms. In countries with poorly functioning institutions and defective bureaucracy, corruption helps to overcome bureaucratic processes, and unclear or complex regulations (Agrawal \& Knoeber, 2001; Khwaja \& Mian, 2005), obstructive private monopolies, and government practices (Voskanyan, 2000).

In a weak institutional environment, it is unlikely that every firm is affected by the corruption in negative ways. Based on the early literature on the grease the wheels hypothesis, Méon and Sekkat (2005) report that corruption can facilitate innovation enhancement in three ways. The first, and well known, argument is corruption can speed up the slow moving permit queue (Luo, 2005), and issue licenses easily and quickly (Bertrand, Djankov, Hanna, \& Mullainathan, 2007; Huntington, 2006), thereby reducing the transaction costs associated with new product or process development. Emerging markets have heavily regulated industries with many requirements (Djankov, McLiesh, \& Shleifer, 2007). As a result, innovative firms may face bureaucratic barriers to obtaining licenses, permits and certifications (D'Este, Iammarino, Savona, \& von Tunzelmann, 2012; Hadjimanolis, 2000), which can restrict entrepreneurial innovation (Anokhin \& Schulze, 2009) by discouraging their capability to introduce new product and process developments. In support of this view, Krastanova (2014) finds that for Bulgarian firms, paying bribes minimises bureaucratic hurdles and speeds up product innovation. Similarly, studies from emerging economies report that bribes facilitate innovation by reducing the status queue. This indicates that a weak institutional environment leads to corruption becoming a second-best solution for firms being innovative. Second, corruption enhances the quality of civil services (Leys, 1965), which may support innovative firms. Supplementation of low wages with gifts and informal payments increases job attractiveness, leading to a better quality of civil services. Third, proponents of greasing the wheels claim that bribes lead to an efficient process for allocating resources, since the most efficient firms will be able to afford to pay the highest bribes.

H1: Paying bribes has a positive effect on MSMEs' firm level core-innovation

H2: The impact of paying bribes on MSMEs' firm-level core-innovation is higher in a weak institutional environment

\section{DATA AND SAMPLE}

The current study extracted data from the World Bank 2017 Enterprise Surveys, which collect data from micro-, small, medium and large size firms. The World Bank's Enterprise Survey database includes both qualitative and quantitative data at the firm level. These surveys comprise a representative random sample of firms with data collected across the world by using the same core questionnaire and same sampling method. The most recent Enterprises survey provides data for seven South American countries. We examine all seven: Argentina, Bolivia, Colombia, Ecuador, Paraguay, Peru and Uruguay.

The first dependent variable of this study is the Core innovations (Core innovaton), which captures either product innovations and/ or process innovations occurring in a firm during the last three years. In their studies, (Gorodnichenko \& Schnitzer, 2013; Mahagaonkar, 2010) used the same proxy to measure core innovation. 
Product innovation (Product) designates a firm has introduced new or significantly improved products or services during the last three years. In their studies, used the same proxy to measure product innovation.

Process innovation (Process) designates that a firm has introduced any new or significantly improved process during the last three years. These include (i) method of manufacturing products or offering services; (ii) logistics, delivery or distribution methods for inputs, products or services; or (iii) supporting activities for processes.

The stream of literature in emerging markets has recently shifted towards direct measures of innovation (Gorodnichenkao, Schniter, 2013; Ayyagari et al., 2014) for several reasons. Most obviously, the traditional measures of innovations such as R\&D expenditure and patent are less likely to be observable in domestically owned small firms and in emerging markets (Gorodnichenko \& Schnitzer, 2013) (Gorodnic, 2013). There are doubts concerning the propriety of using $R \& D$ as an innovation proxy for emerging markets SMEs appearing in the literature because not all innovations are generated by R\&D disbursement (Gorodnichenko \& Schnitzer, 2013), formal R\&D measures are favorable for large firms (Archibugi \& Sirilli, 2001) and, $R \& D$ is input rather than output oriented and not all $R \& D$ necessarily leads to innovation. Also, capturing the catching up process of innovation is important for MSMEs in emerging markets. Therefore, the proxies above adequately capture both the innovations that are new to the firm and those that are new to the world.

However, we do understand, self-reported measures of innovations are more prone to measurement errors and biases than more objective measures such as R\&D and patents. Prior research also acknowledges the subjectivity of these self-reported measures of innovation (see (Gorodnichenko \& Schnitzer, 2013). Nevertheless, in a given context the majority of sample MSMEs are not engaged in R\&D and patents (less than $1 \%$ report $R \& D$ expenditure and patents).

Our main independent variable is Bribes. It has been derived from the following interview question in the Enterprise Survey:

In a recent study, Ayyagari et al. (2014), use the same question to measure the bribe payments for innovative firms. Wellage et al. (2018) use the same question for proxy bribes in their South Asian SME sample. Both papers note caveats in their measures. In their study, Birhanu, Gambardella, Valentini, (2016) also indicate the potential measurement errors of the proxy above. However, it is difficult to find a paper trail for corrupt activities. Therefore, this question represents the best available information to create a Bribes proxy. The World Bank takes several precautions in its surveys to reduce measurement errors in the Bribe variable. First, in line with the empirical research on the corruption theme, the question refers to 'establishments like this' to help provoke truthful responses (Billon \& Gillanders, 2016). This indirect formulation of the question implies that respondents are not asked to confess that their establishment has paid bribes but to gauge the behavior of similar types of establishment. Although seemingly less precise, this approach reduces selfcensorship biases in socially sensitive research (Fisher, 1993). Second, data collection is carried out independently and unconnected with government officials. Third, the World Bank ensures the anonymity of participants.

Also, nonresponsive and measurement errors are clearly visible in prior cross-country studies, which determines the impact of bribery on firm growth (Ayyagari et al., 2014). We use the following two-step process to minimize these biases in our study. First, we use a dichotomous variable of bribes, instead of using an exact bribe amount. Innovative firms may exaggerate or under-report bribe amounts (Ayyagari et al., 2014), therefore, a dummy variable of bribes may be more accurate. Due to the high current political instability, insecure environment and impending crisis in the South American region, many MSME owners/managers may decline to disclose the exact bribe amounts that they pay to the public officials.

Second, we control survey nonresponse biases using the propensity score method. In their studies, Ayyagari, Demirgüç-Kunt, and Maksimovic (2014) and Wellalage, Locke, and Samujh (2018) use a regression technique which assumes that the impact of bribes on innovation will be constant across all firms. The propensity score approach can avoid this limitation and largely counter the missing data problem (Austin, 2011). 
From the survey question above, we have calculated the following variable:

Bribes: This variable is a dichotomous variable and shows whether the firm is paying a bribe. It takes value 1 if the firm makes gifts or informal payments to public officials to get things done about customs, taxes, licenses, regulations, services, etc., otherwise 0 .

\section{METHOD}

The direct compression of firms who paid bribes and others that do not leads to an identification problem. The paying of bribes may correlate with both observable and unobservable factors of firms. If the study fails to correct for this bias, the estimates will give naïve and overestimated results of the impact. Following Rosenbaum and Rubin (1983), we perform PSM to pair firms that pay bribes with other firms that are like them, except for bribes. It is then assumed that the matched firms would have no systematic differences in response to the treatment (paying bribes), so they provide valid counterfactual evidence.

The ATT is obtained by averaging these differences across the m matches:

$$
A T T=\frac{1}{m} \sum_{j=1}^{m}\left[y_{j}^{j \in B=1}-y_{j}^{j \in B=0}\right]
$$

Following Li (2013), we used four major steps to estimate the propensity score causal effect: first step: estimate the propensity score using observational covariates; second: check balance of propensity scores stratum after stratifying the propensity scores into different strata; third calculate the treatment effect (ATT) by selecting appropriate propensity score methods; and fourth: conduct a sensitivity test to justify that the estimated ATT is robust.

\section{RESULTS}

Table 1. The impact on bribes on innovation: propensity score matching (PSM)

\begin{tabular}{lrrrrr}
\hline & No. treated & No. contr. & ATTa & Std.Err & $\mathrm{t}$ \\
\hline Core innovation & & & & & \\
Nearest neighbour matching & 223 & 225 & 0.080 & 0.040 & 2.013 \\
Kernel matching & 223 & 2582 & 0.111 & 0.028 & 3.933 \\
Radius matching (radius=0.01) & 61 & 2575 & 0.105 & 0.052 & 1.992 \\
Stratification matching & 222 & 2943 & 0.110 & 0.030 & 3.666 \\
\hline
\end{tabular}

Note: an ATT means average treatment effect on the treated.

Firm level covariates are included in all models for firm size (micro- \& small and medium), financing type (formal_fund), firm legal status (company), firm ownership types (female_ownership, Foreign _own, government_ownership) firm age, firm quality certificate (quality_certificate), bureaucratic complexity (manager_time) and industry (manufacturing).

The standard error used to compute the t statistics is the standard deviation of the ATT after 100 bootstrap replications.

Table 2. Product and Process innovation: propensity score matching (PSM)

\begin{tabular}{lrrrrr}
\hline \multicolumn{1}{c}{ Product Innovation } & No. treated & No. contr. & ATTa & \multicolumn{1}{c}{ Std.Err } & $\mathrm{t}$ \\
\hline Nearest neighbour matching & 223 & 224 & 0.055 & 0.045 & 1.211 \\
Kernel matching & 223 & 2582 & 0.096 & 0.035 & 2.738 \\
Radius matching (radius=0.01) & - & - & - & - & - \\
Stratification matching & 222 & 2943 & 0.095 & 0.028 & 3.340 \\
\hline \multicolumn{1}{c}{ Process Innovation } & & & & & \\
\hline Nearest neighbour matching & 223 & 224 & 0.113 & 0.055 & 2.065 \\
Kernel matching & 1387 & 1759 & 0.409 & 0.078 & 5.236 \\
Radius matching (radius=0.01) & - & - & - & - & - \\
Stratification matching & 222 & 2943 & 0.114 & 0.029 & 3.870 \\
\hline
\end{tabular}

Note: Radius matching is not performed with given data limitation

Firm level covariates are included in all models for firm size (micro \& small and medium), financing type (formal_fund), firm legal status (company), firm ownership types (female_ownership, Foreign _own, 
government_ownership) firm age, firm quality certificate (quality certificate), bureaucratic complexity (manager_time) and industry (manufacturing).

The standard error used to compute the $t$ statistics is the standard deviation of the ATT after 100 bootstrap replications.

\section{DISCUSSION AND CONCLUSION}

Although corruption is a major concern in emerging economies (Mauro, 1995; Méon \& Weill, 2010; Wei, 2000), how corruption affects innovation has received limited attention (Habiyaremye \& Raymond, 2013). Innovation is identified as one of the key drivers of the economy. Therefore, firm innovations are essential for sustainable economic development and growth as these help in value creation, infrastructure development, and employment of a country. However, in many countries, innovators face corruption as an obstacle and end up paying bribes for the government officials to get things done. Based on the view of development experts, corruption negatively affects firm innovations and may hamper the economic growth to a greater or lesser degree, but this is not common to all countries. In some emerging countries, corruption enhances innovation as it helps innovators to overcome the bureaucratic barriers and obtain their permits and certificates with less hassle.

\section{REFERENCES}

Agrawal, A., \& Knoeber, C. R. (2001). Do some outside directors play a political role? The Journal of Law and Economics, 44(1), 179-198. doi:10.1086/320271

Ahlstrom, D., Bruton, G. D., \& Lui, S. S. (2000). Navigating China's changing economy: Strategies for private firms. Business Horizons, 43(1), 5-5. doi:10.1016/S0007-6813(00)87382-6

Anokhin, S., \& Schulze, W. S. (2009). Entrepreneurship, innovation, and corruption. Journal of business venturing, 24(5), 465-476. doi:https://doi.org/10.1016/j.jbusvent.2008.06.001

Archibugi, D., \& Sirilli, G. (2001). The direct measurement of technological innovation in business. in "Innovation and enterprise creation: Statistics and indicators. Paper presented at the Proceedings of the conference held at Sophia Antipolis.

Austin, P. C. (2011). An introduction to propensity score methods for reducing the effects of confounding in observational studies. Multivariate behavioral research, 46(3), 399-424. doi:https://doi.org/10.1080/00273171.2011.568786

Ayyagari, M., Demirgüç-Kunt, A., \& Maksimovic, V. (2014). Bribe payments and innovation in developing countries: Are innovating firms disproportionately affected? Journal of Financial and Quantitative Analysis, 49(1), 51-75.

Bertrand, M., Djankov, S., Hanna, R., \& Mullainathan, S. (2007). Obtaining a driver's license in India: an experimental approach to studying corruption. The Quarterly Journal of Economics, 122(4), 16391676. doi:https://doi.org/10.1162/qjec.2007.122.4.1639

Billon, S., \& Gillanders, R. (2016). State ownership and corruption. International Tax and Public Finance, 23(6), 1074-1092.

Cuervo-Cazurra, A. (2006). Who cares about corruption? Journal of International Business Studies, 37(6), 807-822.

Cuervo-Cazurra, A. (2008). The effectiveness of laws against bribery aboard. Journal of International Business Studies, 39, 634-651.

D’Este, P., Iammarino, S., Savona, M., \& von Tunzelmann, N. (2012). What hampers innovation? Revealed barriers versus deterring barriers. Research policy, 41(2), 482-488. doi:https://doi.org/10.1016/j.respol.2011.09.008

Djankov, S., McLiesh, C., \& Shleifer, A. (2007). Private credit in 129 countries. Journal of Financial Economics, 84(2), 299-329. doi:10.1016/j.jfineco.2006.03.004

Fisher, R. (1993). Social desirability bias and the validity of indirect questioning. Journal of consumer research, 20(2), 303-315.

Fungáčová, Z., Kochanova, A., \& Weill, L. (2015). Does money buy credit? Firm-level evidence on bribery and bank debt. World Development, 68, 308-322. doi:10.1016/j.worlddev.2014.12.009

Gorodnichenko, Y., \& Schnitzer, M. (2013). Financial constraints and innovation: Why poor countries don't catch up. Journal of the European Economic Association, 11(5), 1115-1152. doi:10.1111/jeea.12033

Habiyaremye, A., \& Raymond, W. (2013). Transnational corruption and innovation in transition economies. 
Hadjimanolis, A. (2000). An investigation of innovation antecedents in small firms in the context of a small developing country. R\&D Management, 30(3), 235-246. doi:https://doi.org/10.1111/14679310.00174

Huntington, S. P. (2006). Political order in changing societies: Yale University Press.

Khwaja, A. I., \& Mian, A. (2005). Do lenders favor politically connected firms? Rent provision in an emerging financial market. The Quarterly Journal of Economics, 120(4), 1371-1411. doi:10.1162/003355305775097524

Kotabe, M., Jiang, C. X., \& Murray, J. Y. (2017). Examining the complementary effect of political networking capability with absorptive capacity on the innovative performance of emerging-market firms. Journal of Management, 43(4), 1131-1156. doi:https://doi.org/10.1177/0149206314548226

Krastanova, P. (2014). Greasing the wheels of innovation: How corruption and informal practices of firms impact the level of innovation in Bulgaria. Central European University.

Leys, C. (1965). What is the Problem about Corruption? The Journal of Modern African Studies, 3(2), 215230.

Li, M. (2013). Using the propensity score method to estimate causal effects: A review and practical guide. Organizational Research Methods, 16(2), 188-226. doi:https://doi.org/10.1177/1094428112447816

Luo, Y. (2005). An organizational perspective of corruption. Management and Organization Review, 1(1), 119-154. doi:

https://doi.org/10.1111/j.1740-8784.2004.00006.x

Mahagaonkar, P. (2010). Corruption and innovation. In Money and ideas (pp. 81-97). doi:https://doi.org/10.1007/978-1-4419-1228-2_5

Mauro, P. (1995). Corruption and growth. The Quarterly Journal of Economics, 110(3), 681-712. doi: $10.2307 / 2946696$

Méon, P.-G., \& Sekkat, K. (2005). Does corruption grease or sand the wheels of growth? Public choice, 122(1-2), 69-97. doi:https://doi.org/10.1007/s11127-005-3988-0

Méon, P.-G., \& Weill, L. (2010). Is corruption an efficient grease? World Development, 38(3), 244-259. doi:10.1016/j.worlddev.2009.06.004

Nations, U. (2006). Millennium Development Goals Retrieved from http://www.unis.unvienna.org/unis/en/topics/2013/mdg.html

Reinikka, R., \& Svensson, J. (2005). Fighting corruption to improve schooling: Evidence from a newspaper campaign in Uganda. Journal of the European economic association, 3(2-3), 259-267. doi:10.1162/jeea.2005.3.2-3.259

Rosenbaum, P. R., \& Rubin, D. B. (1983). The central role of the propensity score in observational studies for causal effects. Biometrika, 70(1), 41-55. doi:https://doi.org/10.1093/biomet/70.1.41

Tanzi, V., \& Davoodi, H. R. (1997). Corruption, public investment, and growth. IMF Working Paper No. 97/139. Washington, DC.

Voskanyan, F. (2000). A study of The effects of Corruption on Economic and Political Development of Armenia. Un published Master thesis, American University Of Armenia, USA.

Wei, S. J. (2000). How taxing is corruption on international investors? The Review of economics and statistics, 82(1), 1-11. doi:10.1162/003465300558533

Wellalage, N. H., Locke, S., \& Samujh, H. (2018). Corruption, Gender and Credit Constraints: Evidence from South Asian SMEs. Journal of Business Ethics, 1-14. doi:https://doi.org/10.1007/s10551-018$\underline{3793-6}$ 